\title{
Artelogie
}

Recherche sur les arts, le patrimoine et la littérature de l'Amérique latine

$4 \mid 2013$

Fêtes et célébrations en Amérique latine

\section{As celebrações, a comunidade e o poder. Os faustos reais de Carlos III e os múltiplos sentidos das festas}

Les célébrations, la communauté et le pouvoir. Les Fastes Royaux de Charles III et plusieurs sens de la fête

\section{Maria Cristina Bohn Martins}

\section{(2) OpenEdition}

\section{Journals}

Edição electrónica

URL: https://journals.openedition.org/artelogie/6146

DOI: $10.4000 /$ artelogie.6146

ISSN: 2115-6395

Editora

Association ESCAL

Refêrencia eletrónica

Maria Cristina Bohn Martins, «As celebrações, a comunidade e o poder. Os faustos reais de Carlos III e os múltiplos sentidos das festas», Artelogie [Online], 4 | 2013, posto online no dia 02 fevereiro 2013, consultado o 01 dezembro 2021. URL: http://journals.openedition.org/artelogie/6146 ; DOI: https:// doi.org/10.4000/artelogie.6146

Este documento foi criado de forma automática no dia 1 dezembro 2021.

Association ESCAL 


\title{
As celebrações, a comunidade e o poder. Os faustos reais de Carlos III e os múltiplos sentidos das festas
}

\author{
Les célébrations, la communauté et le pouvoir. Les Fastes Royaux de Charles III \\ et plusieurs sens de la fête
}

Maria Cristina Bohn Martins

\begin{abstract}
"Quando se é historiador, que fazer se não desafiar o acaso, propor razões, quer dizer, compreender? Mas compreender não é fugir para a ideologia, nem dar um pseudônimo ao que permanece oculto. É encontrar na própria informação histórica o que a tornará pensável". M. de Certeau (2006)
\end{abstract}

1 São Francisco de Borja era, em 1760, uma das várias missões da Província da Companhia de Jesus no Paraguai. Fundada em 1682 numa região de extensas planícies às margens do Rio Uruguai, a localidade fazia parte de um conjunto de 30 povoados $^{1} \mathrm{em}$ que viviam em torno de cem mil índios, e onde os jesuítas conduziam seu apostolado de "missão por redução" junto aos guaranis. Prósperas e bem edificadas, as "missões guaranis" eram laureadas como modelo bem sucedido de "civilização e catequese dos índios", inclusive na Europa ${ }^{2}$. Todavia, não lhes faltavam também detratores, que acusavam os padres de angariarem riquezas desmedidas, bem como de desfrutarem excessiva autonomia e poder. Sob este aspecto, os jesuítas pareciam estar na contra-mão da política regalista em curso na Península, a qual ganharia seus contornos mais expressivos durante o reinado de Carlos III, soberano entronizado em fins de 1759, num momento que era especialmente delicado para as missões.

De fato, desde a chegada das notícias sobre a celebração do Tratado de Madrid entre Espanha e Portugal em 1750, as comunidades das reduções haviam experimentado fortes sobressaltos ; algumas delas, diretamente atingidas pelo acordo, tinham inclusive conhecido dias de guerra recentemente terminados. Por isto mesmo, quando em 
novembro do ano da graça de 1760, o "Pueblo de San Francisco de Borja" comemorou os faustos reais de Carlos III, o evento se revestiu de especial significado, tema que é objeto de análise deste trabalho.

\section{"Viva o Rei, triunfe e impere" : Festas reais em São Borja}

3 O dia quatro de novembro de 1760 amanheceu ao som de salvas de artilharia em São Francisco de Borja. Logo depois, uma missa solene foi oficiada pelos jesuítas José Inácio Umeres, Francisco Xavier Limp e José Cardiel, a qual se seguiu um "banquete" para quarenta convivas. Entre os comensais estavam oficiais e eclesiásticos presentes na missão. Além dos religiosos já mencionados, participaram também o Pe. Diogo de Horbegozo, o Irmão Ruperto Talhamer, o capelão de D. Pedro de Cevallos pertencente à Ordem dos Mercedários, e um frei que atuava como capelão dos oficiais da Comissão Demarcadora, isto é, dos examinadores encarregados de precisar os limites meridionais das duas monarquias ibéricas nas Américas. Como veremos, a presença de oficiais e sacerdotes de variados pertencimentos institucionais indicava as fortes transformações pelas quais haviam passado as missões guaranis após a Guerra de 1753-1756. A partir daquele dia, várias homenagens se sucederam celebrando a coroação de Carlos III $^{3}$ da Espanha, e o aniversário de sua esposa, a rainha Maria Amália, que deveria transcorrer logo depois, em 24 de novembro ${ }^{4}$. Em um destes tributos, na referida manhã, corais de índios guaranis se apresentaram entoando uma canção que repetia a cada estrofe : "Viva o Rei, triunfe e impere. Quem a encher de favores a Espanha vem" (BREVE RELACIÓN [1760]. Apud : SEMPÉ, 1983 : p. 144-145).

4 Preparando a solenidade, a praça central da missão havia sido especialmente enfeitada com guirlandas e arcos de flores, entre outros elementos de "arquitetura efêmera". Além disto, uma iluminação peculiar fora preparada para a noite, de maneira que, quando esta chegou, "a todos parecia haver salido el resplandor del día" (BREVE RELACIÓN [1760]. Apud : SEMPÉ, 1983 : p. 138). Músicos vindos de Todos os Mártires, Santo Tomé e Apóstolos, também se faziam presentes, trazendo suas harpas, violinos e clarins. Já os soldados, dispostos em linhas bem ordenadas e ao som de tambores, caixas e clarins, desfilaram todos os dia da festa pela praça em que tradicionalmente haviam transcorrido os mais importantes momentos da vida da comunidade.

5 Na homenagem prestada ao rei naquela alvorada de quatro de novembro, revezaram-se dois conjuntos musicais. Um deles era proveniente do povoado de Todos os Mártires e o outro de São Tomé, e suas vozes "todos diziam que competem com as afamadas de várias catedrais da Europa" (BREVE RELACIÓN [1760]. Apud : SEMPÉ, 1983 : p. 145). Os jesuítas responsáveis por estas missões, colaboravam por meio do talento dos seus liderados, para solenizar a chegada ao trono do governante que, paradoxalmente, seria o responsável pelo decreto que determinou a sua expatriação poucos anos depois.

Atos de tributo aos monarcas não se constituíam em uma novidade nestas missões. Ao contrário, ainda que as celebrações regulares nos "pueblos" jesuítico-guaranis fossem especialmente de caráter religioso, a comemoração de motivos "civis", em particular quando envolviam acontecimentos referentes à Família Real, não eram excepcionais. Também não era incomum que estes dois âmbitos, o profano e o religioso, estivessem associados em tais oportunidades. 
7 De fato, e não apenas nas reduções, mas nas sociedades governadas pela Monarquia Católica, a festa navegava no marco de uma relação especular entre o religioso e o profano, como pólos que só podiam ser entendidos de forma relacional (MARTINS, 2006). Ou, na formulação de Durkheim (2003), o profano adquiria existência apenas frente ao sagrado.

8 Assim é que as festas cívicas organizavam-se incorporando vários ritos religiosos e estavam saturadas de uma linguagem de base nitidamente cristã. $O$ que se apresenta como singular na situação aqui descrita é o papel central que nela ocupam as autoridades leigas presentes em São Borja, ficando os padres relegados a uma condição secundária em um cenário que haviam ocupado com protagonismo até então. A tentativa de compreender este dado é o escopo desta reflexão que se faz seguindo aquilo que informa a "Relación de las Fiestas Reales de S. Borxa" produzida em 28 de novembro de $1760^{5}$.

\section{Uma década conturbada : "Todo es un alboroto, y me temo que descargarán sobre nosotros"}

Os festejos reais de 1760 transcorridos em São Borja pertenciam a uma categoria de cerimônia de caráter eminentemente público. Assim como bodas e funerais, as entronizações eram objeto de elaboradas celebrações nas cidades principais (com comédias, corridas de touros e fogos de artifício, por exemplo), ou de comemorações mais modestas em localidades pequenas e pobres (MARTINS, 2006). Foi o que ocorreu no momento da coroação de Carlos III, quando apenas quatro anos haviam se passado desde o final da "Guerra Guaranítica" (1753-1756), conflito que esteve diretamente relacionado às disposições do Tratado de Madrid, celebrado entre as monarquias ibéricas sobre as fronteiras de seus respectivos territórios americanos.

O acordo implicava, entre outras coisas, em que a Espanha cedia para Portugal parte do território que ocupavam os chamados "Trinta Povos das Missões" em troca da Colônia de Sacramento. Mais especificamente, passariam para a Coroa portuguesa as sete missões estabelecidas na margem oriental do rio Uruguai, que eram as de mais recente fundação no conjunto geral das reduções ${ }^{6}$. Não atingidos diretamente pelo acordo, alguns outros povoados ficavam, entretanto, com o acesso prejudicado aos seus ervais e estâncias.

11 Em contrapartida ao reconhecimento da expansão territorial lusa por sobre territórios que os limites virtuais de Tordesilhas reconheciam como espanhóis, a Monarquia Bourbônica pretendia assegurar para si o uso exclusivo do Rio da Prata, desarticulando práticas de comércio irregular lideradas por portugueses e ingleses. As autoridades pretendiam assim, reorientar os circuitos comerciais que, a partir de Sacramento, drenavam por meio do contrabando as rendas que eram imprescindíveis para enfrentar o crônico déficit fiscal do país ${ }^{7}$.

Uma vez que a permuta atingia diretamente as sete missões assentadas na margem direita do rio Uruguai, foi ordenado aos padres que as transladassem para o lado oposto, reconstituindo-as para que ficassem dentro dos limites de jurisdição espanhola. Os guaranis poderiam levar consigo suas armas, ferramentas, utensílios e rebanhos, recebendo uma pequena indenização pelo que ficava para trás ${ }^{8}$. As negociações foram conduzidas em sigilo mas, ao se tornarem públicas, as dificuldades práticas de conduzir 
a operação e os rumores sobre o destino que estaria reservado aos índios, fizeram estalar a sua oposição. Depois disto, organizados a partir de sua experiência prévia como "milicias del rey", os guaranis deram início a uma guerra contra as forças espanholas e portuguesas.

A oposição mais decidida partiu dos moradores de São Miguel e São Nicolau, reduções que faziam parte daquelas comunidades de que se solicitava agora, o deslocamento. A resistência se espalhou pelos povoados e desestabilizou as negociações do tratado, afinal nunca executado. Ela implicou em um elevado desafio para a autoridade real e lançou fortes suspeitas sobre a participação dos jesuítas na condução dos acontecimentos. Estas desconfianças foram alimentadas pelas iniciativas dos padres no sentido de reverter as ordens recebidas e de seu esforço para, por meio de cartas e informes, demover as autoridades da decisão de forçar a retirada dos "Sete Povos". Tais circunstâncias geraram uma profusão de notícias acerca de presumidas riquezas existentes nas missões, das quais se aproveitariam em benefício próprio os inacianos, mas, especialmente, alimentaram as já consistentes críticas contra suas supostas tendências autonomistas 9 .

14 Segundo muitos acreditavam, as missões do Paraguai constituíam o território de um Estado independente, erigido a partir do mando dos jesuítas e do trabalho que eles arrancavam de índios completamente submissos. Sabemos que, além de missões e colégios, os jesuítas na América dirigiam estâncias e "haciendas" que, de resto, proporcionavam os meios econômicos para sustentar suas atividades. A exitosa economia destas, derivada de uma rigorosa e eficiente estrutura administrativa e de uma disciplinada condução do trabalho, permitindo aos jesuítas uma capacidade financeira que se destacava em uma área pobre e marginal. Tal inserção na vida civil fazia da Ordem uma rival dos setores "criollos" da sociedade, que a consideravam uma competidora desigual, haja vista contar com a mão de obra dos índios, além de isenções fiscais para as reduções. Esta realidade não franqueou aos padres a benevolência dos colonos, que se percebiam lesados diante de recursos aos quais não tinham acesso.

Não é demais recordar que as acusações de que a prominência dos jesuítas sobre os índios das missões usurpava a monárquica, e que eles haviam promovido e organizado a sua rebelião em causa própria, se desenvolviam justamente na contramão dos interesses em curso na Espanha a partir da chegada ao trono da Casa de Bourbon. Ao longo do XVIII, com especial ênfase na época em que governou Carlos III (1759-1788), foram realizados ambiciosos projetos do "despotismo ilustrado", no intuito de modernizar a administração do Reino, recuperar sua economia e reforçar a autoridade monárquica. Entre as ações tomadas neste sentido estiveram medidas para reverter o poder político e econômico angariado pelo clero no Novo Mundo. Várias delas contiveram as faculdades da Igreja, tais como a proibição de publicar documentos pontifícios no império espanhol sem a prévia autorização do monarca, a limitação do direito de asilo nos templos e as restrições sobre a imunidade pessoal dos padres. A incriminação dos jesuítas por reações contrárias a estas e outras iniciativas, seria decisiva para decretar a expropriação dos bens da Ordem e sua expulsão da Espanha e de suas colônias em fevereiro de 1767.

Desta forma, a Sociedade de Jesus que fora criada sob o signo da modernidade e renovação, aparecia agora simbolizando tradições que se colocavam na contramão da reforma e do progresso. As tendências assim assinaladas, embora já tivessem conhecido um período de elaboração e maturação ${ }^{10}$, seriam especialmente caras a Carlos III e seus 
ministros, justamente o monarca cuja chegada ao poder era saudada em São Borja naquele quatro de novembro.

\section{Os jesuítas, os índios e os conflitos no Rio da Prata : o preço da paz}

No Rio da Prata, o Tratado de Madrid foi recebido com espanto e desconcerto e, tanto os jesuítas como as autoridades das jurisdições de Buenos Aires, Paraguai e Tucumán, encaminharam correios solicitando serem escutados sobre suas determinações. Muitas destas cartas circularam dentro dos espaços americanos, mas algumas se dirigiram a interlocutores europeus. Segundo Lia Quarleri, é notável que as demandas dos padres não tenham sido dirigidas imediatamente ao monarca: "Las primeras cartas $y$ representaciones en las que se reclamaba una revisión de las consignas más controvertidas del Tratado [...] estuvieron dirigidas al virrey del Perú y a la Audiencia de Charcas. Luego a los comisionados nombrados [...] para poner en practica el tratado en el Río de la Plata. Más tarde al confesor real y por último a Fernando VI" (QUARLERI, 2009 : p. 130).

Uma mirada em retrospectiva permite avaliar o quanto os jesuítas do Paraguai e seus superiores europeus construíram avaliações distintas sobre os eventos em curso. Enquanto os primeiros anunciavam seu temor de que a execução das ordens recebidas resultaria em perigosa quebra da confiança que os índios depositavam em seus padres (condição necessária para a viabilidade das missões), os segundos se mostravam temerosos da repercussão que as avaliações dos "americanos" teriam na Europa. As autoridades e missionários do Paraguai, desconsiderando as diretivas dos dirigentes europeus, se pronunciaram contra o tratado, "ya que creían poderosamente en su injusticia y se sentían afectados y comprometidos con quienes compartían cotidianamente su vida". Além disto, a distância aparentemente "les proporcionó cierta inconsiencia [...],sobre cómo eran leídas sus críticas en la escena política europea, y por esto es que insistieron en advertir sobre las complejidades del traslado y los errores en que se incurriría con la permuta de los territorios" (QUARLERI, 2009 : p. 145).

Não resta dúvida de que as manifestações dos jesuítas geraram grande desconforto e a suspeição de que eles nutriam a rebeldia dos índios. Muitos padres viviam entre os guaranis já a longos períodos, excedendo duas décadas em alguns casos. Enquanto a alguns se lançaram acusações sobre seu pouco empenho em fazer cumprir as ordens, outros foram denunciados como culpados de traição ao rei, como ocorreu com Luis Charlet, Tadeo Henis e Xavier Limp. Houve ainda quem assumisse publicamente posições que se aproximaram quase da insubordinação, e quem fosse punido por isto, como ocorreu com Jose Cardiel que, junto com Limp, participou das festividades de São Borja em 1760.

Havia sido como residente nesta missão que Cardiel, dois anos antes, escrevera sua "Declaración de la Verdad" (1758), libelo inflamado contra aquilo que entendia ser uma campanha de difamação sobre a Ordem. Pelas posturas que assumiu, reveladas em cartas onde desqualificava as determinações do Tratado, foi-lhe imposta a pena de silêncio, o que o impedia de se pronunciar sobre os episódios em curso ; foi-lhe também cominada a obrigação de ajudar a pacificar os povoados e acompanhar - como capelão o exército dos demarcadores. 

Visconti para fazer cumprir o acordo- fez parte do esforço da Companhia em não aumentar as perdas políticas resultantes do imbróglio. A suposição de que, a partir das instâncias das autoridades, os padres levariam adiante o que lhes era proposto, não considerou a reação que viria dos guaranis. De algum modo esta compreensão equivocada decorria da imagem que os próprios jesuítas, através de inúmeras narrativas, haviam ajudado a construir. Isto é, seus cronistas e historiadores, assim como suas correspondências oficiais ${ }^{11}$, haviam contribuído para superdimensionar a autoridade dos jesuítas diante dos "dóceis" guaranis.

Cardiel, por exemplo, em um texto de 1747 (1953 : p. 161), destacava a sujeição dos guaranis, "tan sin rastro de rebelión, tan sin mostras de amotinarse, ni en sus pueblos, ni en el discurso de la función militar, que antes bien ellos son los que sosiegan cualquier motín de españoles". Valorizando de forma exagerada a ascendência dos padres e a obediência dos índios, o jesuíta não se considerava, portanto, o fato de que as reduções haviam se constituído a partir de um intrincado sistema de relações e negociações que implicavam, entre outras coisas, em concessões mútuas que eram construídas e testadas diariamente.

De acordo com o que observou Quarleri (2009 : p.151), se a adesão dos cabildos de cada missão às ordens de transmigração podia ser obtida com menor dificuldade (uma vez que suas autoridades eram designadas diretamente pelos padres), muito mais delicada era a situação junto à meia centena de caciques que havia nos sete povoados. Foram em boa medida estes caciques que se manifestaram em cartas que, dirigidas ao rei, lamentam contra a medida e buscam a sua reversão : "Nuestro Santo Rey no sabe [...] lo que es nuestro pueblo ni lo mucho que nos ha costado [...] más de cien años hemos trabajado nosotros, nuestros padres y nuestros abuelos para [...] ponerlo en el estado que al presente tiene, habiendo todos tolerado [...] por tan dilatado tiempo increibles fadigas hasta derramar nuestro sangre para concluirlo ... "(apud : MELIA, 1986 : p. 186)

Uma e outra vez as cartas se referem ao fato de que os índios não querem a guerra, mas que a enfrentarão para defender "sus pueblos". Foram especialmente estas lideranças que organizaram a resistência, afinal mal sucedida para os guaranis derrotados em 1756. Com a vitória das tropas luso-espanholas ocorreu o seu avanço no espaço até então controlado pelas missões. Apesar de esporádicas tentativas de oposição dos índios, em maio daquele ano o governador José de Andonaegui ocupou, com 400 homens, o povoado de São Miguel que tinha sido o centro da rebeldia. A partir desta redução, que encontrou vazia e em chamas, Andonaegui exigiu certo "ritual"12 de rendição envolvendo os caciques e os curas.

Segundo um contemporâneo dos acontecimentos, o padre Juan de Escandón, Procurador Geral da Companhia em Madrid, atenderam ao chamado do governador o Pe. Inocêncio Herber de São Luís, o cura ajudante de San Juan [já que Luis Charlet, responsável pela missão, alegou estar doente] e Jaime Mascaro de São Borja (ESCANDóN [1760], 1983 : p. 331). Nem todos povoados manifestaram pronta obediência, como foi o caso de São Nicolau, São Borja e São Lorenzo. Esta última redução foi então ocupada por 800 homens e transformada em quartel general do governador de Montevidéu. Enquanto isto, Gomes Freire de Andrade, governador do Rio de Janeiro e responsável pelas tropas lusas, instalou-se em Santo Ângelo, e Andonaegui, governador de Buenos Aires e comandante das tropas castelhanas, em São João. Esta ocupação representou um divisor de águas na história das reduções e os rituais de obediência que a seguiram 
revelavam uma nova relação de forças. As missões não gozariam mais da relativa autonomia que haviam desfrutado, e os guaranis e seus curas estavam agora sob a sujeição direta dos governadores. Nas três reduções conduziram-se cerimônias festivas de recebimento das novas autoridades, as quais deveriam guardar alguma aproximação com aquela de 1760, embora não devessem ter o fausto e a duração desta última. Mas, em ambos os casos, novos protagonistas apareciam sendo festejados e honrados, o que era uma decorrência da situação naquele momento estabelecida.

Podemos aventar que a participação em tais rituais era uma tentativa, de parte dos jesuítas, de ganhar a boa vontade das autoridades e evitar represálias aos rebeldes, agora em situação de derrotados. Aliás, reforçam esta conclusão algumas passagens da "Breve Relación" ressaltando a boa impressão causada pelos índios aos militares que estavam no povoado. Segundo elas, era notável a mudança de opinião dos soldados e do governador em relação aos guaranis e aos padres que os instruíam (Breve Relación. Apud : SEMPE, 1983 : 122).

Nos meses conturbados que se seguiram ao final da guerra, muitos índios deixaram as reduções, outros entravam em contato com costumes que os padres haviam tentado banir como os jogos de azar e o consumo de álcool ${ }^{13}$. Os povoados que, desde a época das primeiras fundações no século XVII tinham evitado a presença dos colonos, passavam a conviver agora com as tropas de soldados. A "Breve Relación de las Fiestas Reales" nos fala, também, da presença de "vivandeiros e peões", o que está em franco desacordo com a orientação que, até então, haviam imprimido os jesuítas. Estes, desde o século anterior, tinham evitado, sempre que possível, o estreitamente de relações entre os guaranis e a sociedade em seu entorno, uma vez que dela consideravam provirem influências perniciosas. Buscavam assim, na medida do possível, levar a efeito a pretendida separação entre a República de índios e a República de espanhóis, que foi parte da política colonial espanhola na América.

São Francisco de Borja, uma das reduções mais austrais, recebeu, em 1757, o recém empossado governador Dom Pedro Antônio de Ceballos $^{14}$, novo "capitán general" e máxima autoridade para levar adiante o processo de demarcação e permuta de territórios, então em compasso de espera. Em sua marcha passando por São João, onde estava instalado o quartel general dos espanhóis, ele foi recepcionado pelos padres que buscaram apresentar um quadro de obediência e cortesia ao novo mandatário. Tal atitude vai ao encontro do que sabemos sobre o papel do cerimonial nas sociedades do Antigo Regime, em que ele não é apenas uma interpretação metafórica ou especular da ordem, mas ajudava diretamente a instituí-la. Sobre isto, Wilde (2003, p. 26) assegura que "el cerimonial, en tanto que representación, debía reflejar el orden mismo de las cosas". Ademais, tal como se observa aqui, as festas podiam ser ocasiões propícias para resolver pugnas políticas ou para vários atores sociais ajustarem contas entre si ; ou ainda, para disciplinar os conflitos e apaziguar arestas e tensões que agitavam as sociedades.

29 A condução da situação pelos padres nos termos aqui narrados acarretou bons resultados, ainda que momentâneos. Da boa impressão causada pelas recepções festivas que recebeu e da situação de abandono em que se encontravam os povoados, resultou, por parte de Ceballos, uma postura menos hostil aos jesuítas e às reduções, do que havia tido seu antecessor. A já referida dispersão de parte da população guarani que ele pôde verificar foi uma das conseqüências da turbulência daqueles anos, durante os quais muitos indivíduos fizeram escolhas pessoais que podiam conduzi-los para as cidades e 
estâncias onde exerceriam os ofícios para os quais estavam preparados, ou podiam leválos para "as matas", onde buscavam formas antigas de vida. O novo governador acabou se instalando em São Borja, onde o encontramos nos festejos reais de 1760.

\section{As Festas Reais de São Borja : "Hallabase la plaza revestida de arcos esmaltados con laureles"}

São Borja foi constituído em 1682 numa área de planícies onduladas na margem oriental do rio Uruguai como a primeira das fundações que marcariam a "reentrada" dos jesuítas na Serra do Tape, abandonada na década de 30 diante das investidas bandeirantes. As famílias que saíram de Santo Tomé para iniciar o novo assentamento, provavelmente participaram de alguma cerimônia ritual de posse que estabelecesse seus laços simbólicos com o povoado.

Por exemplo, em 1697, o Pe Antônio Sepp, responsável pela fundação de São João Batista, informa que precisou convocar os "caciques principais" de São Miguel e discutir com eles sobre a necessidade de fazer migrar parte das famílias da redução que se encontrava excessivamente povoada. Argumentou-se que não apenas o templo da missão não comportava mais os fiéis, como especialmente que faltavam campos de cultivo suficientes nos arredores. Vinte e um caciques, com suas famílias (750 pessoas) acompanharam Sepp. A partida do grupo foi solene e envolveu elementos de sensibilização coletiva. "Montávamos cavalos bem ajaezados ; os caciques [...] levavam fasces e o capitão [...] estava munido de um bastão, insígnia de supremo juiz", escreveu o religioso. Ainda segundo ele, trombetas e flautas acompanharam a saída do grupo que, ao entardecer, encontrou uma suave colina, "cercada de amenos bosques", nos quais "abundava a madeira necessária não só para combustível, como para construir as casas dos indios, a igreja e a minha moradia". Após verificar condições do lugar, "se era palustre, arenoso, etc., a que ventos estava exposto, se rodeado de montes e bosques, se irrigado por riachos [...] ; [...] por consenso de padres e índios", lançaram-se os fundamentos da nova povoação (SEPP [1692],1980 : p. 201-202).

32 A descrição do religioso bávaro é a única que possuímos sobre os procedimentos envolvidos na fundação das reduções. Ela evidencia os cuidados na seleção do terreno, mas especialmente a importância da adesão dos "principais" ao projeto ${ }^{15}$. Também a solenidade com que se distinguia o início de um novo povoado, o que está em sintonia com a forte ritualização com que os jesuítas buscaram envolver o próprio cotidiano das reduções. Além disto, as cerimônias possivelmente aparecessem aos guaranis como o meio de compor vínculos com o novo espaço e manter aqueles já firmados com os parentes que ficavam no povoado original e com a memória dos antepassados. Isto é, o rito operava aí como mecanismo de reforço ou recriação de alianças baseadas no parentesco e na memória.

33 Ainda segundo Sepp, na outra manhã, foi erigida uma cruz "em sinal da tomada de posse daquela terra". Era a data em que a Igreja venera o "santo lenho". "Portanto, na festa da Santa Cruz, eu também a chantei como pedra fundamental da povoação. Ereto o madeiro, logo os indios, prostrados em terra, o adoraram ; em seguida foi cantado o hino [...] acompanhado por trombetas e tímpanos pelo músico que, para este fim, trouxera comigo ; depois [...] o beijamos, agradecendo [...] os benefícios que nos concedera" (SEPP [1692],1980 : p. 203). 
34 Marcando ainda mais fortemente o caráter cerimonial do evento, Sepp realiza um solene discurso, em que exalta as qualidades da terra e exorta os índios a acolhê-la e torná-la produtiva. Na mesma oportunidade, divide os terrenos entre os caciques e manda erigir "uma cruz a guiza de marco [...] além da qual não era permitido avançar". Finalmente, concluindo o conjunto de atos rituais e solenes, ele lança "sobre a nova colônia a costumada benção dos campos, para expulsar os demônios que, por causa da infidelidade destes gentios, habitavam [...] estes lugares" (SEPP [1692], 1980 : p. 208).

Podemos compreender que, assim como estes, muitos outros laços simbólicos haviam sido cuidadosamente tecidos entre os índios e seus povoados. Sabemos, por exemplo, pelas narrações dos jesuítas, que as atividades de plantio e colheita envolviam seus próprios momentos rituais, assim como a construção e consagração da igreja e das capelas dispostas pelo território da redução. Portanto, embora isto não estivesse evidente para as autoridades civis, a opção por abandonar os "pueblos" diante do que lhes era ordenado pela Coroa envolvia, para os guaranis, muito mais do que a mera obediência às razões de Estado.

Para melhor compreender estes vínculos entre as comunidades e seus povoados, lembremos que as festas do "titular" ou padroeiro de cada uma eram notadamente caras, por exemplo, como momento de pedir proteção ou agradecer por alguma intercessão especial. São Francisco de Borja, São Nicolau, São Miguel Arcanjo, São Lourenço Mártir, São João Batista, São Luiz Gonzaga e Santo Ângelo Custódio foram assim homenageados pelos guaranis e por seus sacerdotes nos dias de sua evocação, em cerimônias que deviam ajudar a manter e reforçar os vínculos que começavam a ser construídos já nos ritos de fundação como aqueles dirigidos por Antonio Sepp.

Os diversos povoados também comemoravam as principais festas do calendário cristão, em especial a Semana Santa, o Natal e Corpus Christi. Esta última data tinha adquirido especial vitalidade com a Reforma Católica, uma vez que Roma reafirmou a doutrina da transubstanciação frente a sua recusa pelas igrejas reformadas. 0 momento de rara solenidade em que o Santíssimo era retirado dos altares e, em procissão, percorria ruas e praças, representava o ponto mais alto do ciclo festivo anual. Um dos elementos essenciais da cerimônia residia no rigoroso posicionamento hierárquico guardado pelas autoridades e pelos diversos componentes da sociedade, de acordo com sua procedência e dignidade. Nas reduções ocupavam lugar central nesta cerimônia os padres, os caciques e membros do cabildo.

Forma concreta e sensorial para compreender o simbólico e o sacramental, festas como estas valorizavam os sentidos ; eram estímulos plásticos que traduziam todo um conjunto de convenções necessário para a catequese. Sob esse aspecto, assumiam a faceta pedagógica de importante recurso para a doutrinação.

No dia-a-dia dos povoados missioneiros as mais diversas ações do cotidiano eram ritualizadas [pelo toque dos sinos, pelas orações ou pelo hinos sacros], enquanto as festas do calendário demarcavam um ciclo ritual mais longo, que transcorria junto com a passagem do ano. Elas faziam parte de um conjunto de eventos oficiais das aldeias, onde consagravam e tornavam públicas as estruturas de poder em vigor. Portanto, as festas tendiam a reiterar a estabilidade das normas e valores. Esse aspecto é muito evidente nas festas de padroeiro, que eram oportunidade não apenas para invocar sua proteção especial, como para solenes juras de fidelidade à Monarquia. 

guaranis divididas em dois corpos, um de infantaria e outro a cavalo. 0 número de cavaleiros chegaria a quinhentos ou mais : parte da própria redução ; parte de visitantes. Em comitiva, os índios deslocavam-se para a praça aclamando o Monarca e fazendo tremular o Estandarte Real, assim como naquela manhã de novembro de 1760 . As insígnias dos cabildos, contudo, não estariam mais presentes nos faustos de Carlos III.

41 Além disto, por tardes inteiras ocorriam "justas, y ejercicios de armas, las carreras de a pie y de a caballo en honra del Santo [...] y del Estandarte Real" (HERNÁNDEZ, 1913 : p. 94). 0 final do dia era marcado pelos sinos chamando para a missa. Depois vinham as danças atravessando a noite iluminada pelas fogueiras : "danzan y entredanzan con gran gusto del pueblo [...] y jamás hay entre ellos una menos decente" [CARDIEL [1781], 1989 : p. 140). Se evidenciava com clareza em tais momentos, o fato de que, nestas sociedades do Antigo Regime, a religião não era elemento de foro íntimo, ato de livre eleição ; ao contrário, a expressão pública da fé era o suporte da condição de súditos dos reis católicos $^{16}$.

Na festa de novembro de 1760 até mesmo as touradas, tão caras ao gosto popular na Espanha e no Novo Mundo, estiveram presentes. Elas duraram três dias. Um dos soldados que participou do evento anotou em verso que "tanto toro bruto y caballero, celebraron a Carlos el Tercero" (Breve Relación. [1760] Apud : SEMPÉ, 1983 : p. 142). Além desta, outras diversões também movimentaram aqueles dias, como três óperas de elevado caráter moral, "sin mesclar en la fiesta acción mundana". Por sua vez os índios, todos muito jovens, entre cinco e vinte anos, cantaram óperas e dançaram inúmeros bailes, de forma que "de tarde y de mañana siempre se bailaba" (Breve Relación [1760]. Apud : SEMPÉ : 1983, p. 142).

43 A decoração do "pueblo", cujo colorido e odores provinham de plantas nativas, era completada pelos fogos instalados em meio à praça. Elemento estruturador da organização dos povoados, ela era o espaço público e aberto em que transcorriam atividades cívicas, religiosas, culturais e esportivas, onde se realizavam as celebrações de colheitas, os desfiles militares, as procissões, os teatros sacros, os jogos esportivos e onde se exercia a justiça. Ali foi colocado "un castillo de fuegos [...] con tal destreza fabricado, que tres veces se vio muy relucente [...] que a los volcones de Sicilia imitaban" (Breve Relación [1760]. Apud : SEMPÉ, 1983, p. 141).

44 A comemoração de datas civis como a de novembro de 1760 não era incomum nas missões. Ao contrário, momentos importantes para a Monarquia, como nascimentos ou bodas reais, vitórias militares ou as coroações como no caso aqui retratado, costumavam ser festejados solenemente. Mesmo outros eventos, de importância e solenidade menor, recebiam atenção. Era o caso, por exemplo, da vinda de autoridades, para o que os povoados se preparavam cuidadosamente.

45 Além dos arcos que ornavam as ruas e praças, os próprios caminhos eram enfeitados para aguardar a chegada das visitas, como registra a Anua de 1634 : "Por octubre vino el [...] Provincial a visitar estas reducciones y [...] fue grande la alegria y [...] hicieron [...] un castillo muy [...] vistoso. Vinieron a recebirle todos los principais casiques, en lo alto del castillo estaban los instrumentos musicos [...], que son unos calabaços que atruenan al ayre. En lo bajo estaban asientos para el Padre Provincial y para los que iban con el [...] y un niño y can[tou] versos y le dio la bien venida en nombre de todos" (CARTA ÂNUA DAS MISSÕES DO PARANÁ E DO URUGUAI, relativa ao ano de 1633, MCA III ${ }^{17}, 1970$ : p. 67 ). 

que exigia esforços coletivos, costumavam estar associadas a "comidas públicas" (isto é, aos "banquetes" de que fala a Relación") que eram oferecidas pelos "principais" aos seus parentes e, se fosse o caso, aos visitantes. É o que encontramos na Anua de 1633, como em tantas outras. Segundo esta carta, em São Fco Xavier o trabalho de erguer a cruz do povoado foi saudado com "mucha [...] algazarra en señal de regozijo" e seguido de uma refeição coletiva para animar os índios na edificação das casas da missão (CARTA ÂNUA DAS MISSÕES DO PARANÁ E DO URUGUAI, relativa ao ano de 1633, MCA III, 1970 :p. 67 ).

Tais "comidas" eram complementos das festas mais importantes. Nestes casos, grandes mesas eram instaladas nas praças, ou nos pátios e arcadas das casas. Cada uma era dirigida por uma autoridade, especialmente caciques e cabildantes. "Casi en cada fiesta y venida de viaje, hay banquetes [...]. Hácenlos, no dentro de sus casas, sino en los soportales. Disponen [...] mesas en diversos sitios: de cada una cuida uno de los principales que señala el Padre. Dales el Padre por la mañana una vaca para cada mesa. Ellos la aderezan en su casa ; y añaden de sus bienes batatas, mandiocas y legumbres" (CARDIEL [1771], 1989 : p. 136).

Cada cacique servia em sua mesa o melhor de que dispunha, afiançando sua obrigação de ser generoso para com seus liderados ${ }^{18}$. De acordo com o Pe Peramás "para que la comida fuese más espléndida se distribuían [...] algunos víveres del fondo común" (Apud: FERNÁNDEZ HERRERO, 1992: p. 363). O Padre fazia a benção dos alimentos e os corais cantavam para os participantes ${ }^{19}$; uma "ação de graças" que completava o dia, de forma a agradecer-se a fartura de alimentos colocada à disposição dos participantes.

Os rituais de comensalidade davam oportunidade para o estreitamento de relações de amizade com os convidados, o que era ainda favorecido pela distribuição de presentes. Uma grande quantidade de objetos como facas, navalhas, pentes, chapéus ou contas de vidro, ou ainda sal, erva e tabaco "cosas todas que ellos estiman mucho", eram repartidos, sendo que "para cada convidado se pone cantidad de estas cosas ..." (CARDIEL, 1989 [1771], pp. 143-144).

Diante de certa emulação assumida em tais oportunidades, as autoridades da Província tiveram que regulamentar as visitas. Este cuidado está expresso no "Regulamento Geral das Doutrinas" de 1689 que normatizou a participação dos diversos povoados nas festas uns dos outros. $\mathrm{O}$ artigo 14 do Regulamento estabelece a "teia" de convites permitidos, e nos ajuda a compreender a participação da gente de São Tomé nos festejos reais de São Borja de 1760 : "las Doctrinas de Loreto, Corpus y San Ignacio se corresponderán entre sí y no con otras. Las de Santa Ana, Candelaria y Itapúa se corresponderán entre sí y no con otras. Las de San Javier, los Mártires y Santa María, se corresponderán entre sí y no con otras. San Nicolás, San Luis y San Miguel se corresponderán entre sí y no con otras. Asimismo Santo Tomé y San Borja se corresponderán entre sí y no con otras : y lo mismo La Cruz y Yapeyú" (Apud : HERNÁNDEZ, [1689], 1913 : p. 594).

O documento faz também restrições : "No se conviden [...] los acólitos ni los músicos de otras Doctrinas, sino solas dos ó tres voces buenas, si la Doctrina en que se celebra la fiesta carece de ellas. Los Corregidores y gente principal de las Doctrinas que se corresponden se podrán convidar" (Apud : HERNÁNDEZ, [1689], 1913, p. 594). Ficava assim estabelecido até onde podiam chegar os convites e quem poderia ser destinatário deles : autoridades e, eventualmente, músicos das reduções mais próximas. A necessidade de estabelecer normas sugere que a prática escapara aos objetivos próprios desse tipo de evento, estabelecendo-se prejudicial competitividade entre os povoados. Na celebração de São 
Borja contudo, também esta regra foi desconsiderada, dada a presença de cento e setenta músicos visitantes (Breve Relación [1760]. Apud : SEMPE, 1983 : p. 142).

Importa aqui destacar que, percorrendo a documentação sobre tais eventos especialmente as Cartas Anuas, as Crônicas e Histórias da Companhia de Jesus - iremos verificar que ela registra de maneira unânime a centralidade da participação de caciques e jesuítas (MARTINS, 2006). São estes "sujeitos coletivos" que concentram o protagonismo dos vários festejos, ao contrário do que podemos perceber em curso no evento de 1760. Por exemplo, nesta última situação, coube ao governador presidir os momentos principais ; o banquete se faz para seus convidados e parte dele a oferta de alimentos aos visitantes: "Chegaron todos juntos no dia 3. Entraram no Povo ao som de clarins [...] todos em ordem, causando grande movimento em todos militares e vivandeiros que, excitados, saíam para vê-los. [...] Logo se encaminharam para apresentarem-se ao general $e$ receber suas ordens [....] Mandou que todos os dias lhes dessem pão, milho, legumes e carne em abundância" (Breve Relación [1760]. Apud : SEMPÉ, 1983 : p. 144). Também é ele quem determina as condições de hospedagem, sob o cuidado de guardas "para evitar desordem", num tipo de referência que a documentação jesuítica, de resto sempre marcada por aspectos de edificação, não costuma registrar. (Breve Relación [1760]. Apud : SEMPE, 1983 : p. 144).

53 Não há dúvida que o evento descrito aparece como uma celebração bastante distinguida daquelas que tradicionalmente transcorriam nos "pueblos". Vários aspectos concorrem para tanto, como o já citado protagonismo que se apresenta deslocado, dos padres e caciques para as autoridades militares ; das comunidade guaranis para os "quarenta convivas" que participaram do "banquete". Os caciques e os membros do cabildo são ausências que merecem destaque, haja vista seu papel proeminente nas festas tradicionais. Nossa fonte silencia sobre eles e, aliás, a sua leitura deixa a impressão de que a maioria dos índios envolvidos na festa é composta por crianças e adolescentes. Finalmente as milícias -os "soldados del rey" que costumavam se apresentar em corpos de infantaria e cavalaria, exibindo o estandarte real e lançando aclamações ao Monarca-, também estiveram compreensivelmente ausentes ${ }^{20}$, em vista dos recentes eventos militares envolvendo os "pueblos".

Que os jesuítas participassem da festa, ainda que, podemos supor, com certo incômodo, é fácil compreender. Igualmente que estimulassem ao máximo os guaranis em abrilhantá-la. A situação que viviam era de enorme instabilidade e a lembrança da recente (1759) expulsão de seus companheiros dos territórios luso-brasileiros, uma ameaça latente.

Meses depois, em fevereiro de 1761, a Espanha admitiu a anulação do Tratado de Limites. Os habitantes das sete missões puderam retornar aos sítios que, por vários meios, inclusive pela guerra, haviam sustentado que eram seus de direito. As reduções contudo, assim como aquilo que poderíamos chamar de "espaço guarani-missioneiro", haviam sofrido profundas mudanças, as quais, como temos apontado, em parte se encontravam traduzidas nos "faustos reales" de São Borja.

Em 1767 o rei celebrado naquela missão distante decretaria a expulsão da Companhia de todos os seus domínios. Nos primeiros meses de 1768, os funcionários do governador Francisco de Paula Bucareli y Ursua chegaram a Yapeju, o povoado mais austral, passando a percorrer cada um deles para desalojar os antigos administradores e instaurar uma nova situação de poder. 

complementando aquele anterior que, em São Miguel, havia exigido dos padres sua pública manifestação de obediência ao governador. De acordo com Guillermo Wilde, em vários "pueblos" os episódios seguem uma mesma sequência : "son recibidos con música y comidas en las afueras de cada pueblo. Acto seguido, realizan la " entrada " [...] con aclamación al Rey en la plaza central y misas en la iglesia. Por último, los funcionarios [...] designan al administrador y al nuevo cura (más tarde confirmado mediante la "toma de posesión canónica"), $y$ confeccionan los inventarios de bienes" (WILDE, 2001 : p. 84).

Os rituais envolvidos na cerimônia estavam destinados a instituir e legitimar uma nova ordem da qual os jesuítas definitivamente não mais participavam, nem mesmo da forma pálida em que os havíamos encontrado naqueles dias em que durou a festa de coroação de Carlos III em São Borja. Embora longa, a rica descrição recolhida por Guillermo Wilde pode ajudar a compreender o argumento acima enunciado. Isto é, o de que este momento completava aquele iniciado em 1756 quando da derrota dos guaranis, em que se exigiu que os padres publicamente oferecessem sua obediência às autoridades seculares de Buenos Aires, bem como a situação posterior, como em São Borja, quando convivem a ascendência dos padres, embora muito diminuída, e a dos militares.

De acordo com um observador que acompanhava os acontecimentos, os membros do cabildo e demais povoadores de São Miguel receberam os encarregados da execução da ordem de expulsão, "con muestras de regocijo y fiesta, manifestándose en todo fieles [...] vasallos del Rey". Mais ainda, eles teriam preparado uma refeição especial "la qual admití con buena voluntad, asistiendo en ella los oficiales que vienen conmigo, y Religiosos, y mientras se comió, toco la música, y cantaron en alabanza del Rey, la misma tarde [fuimos ?] a campar a la inmediación de dicho Pueblo el cual estaba prevenido [...] en el pórtico de la Iglesia enarbolado el Real Estandarte, y un retrato de Su Majestad" (WILDE, 2001 : p. 84).. No dia seguinte, segundo o narrador do evento, uma missa solene foi assistida por todos os religiosos, pelo cabildo e habitantes do povoado. Finalmente, as duas da tarde avisou-se a eles que "era llegada hora de ejecutar la Orden del Rey y que ellos con su obediencia darían buen ejemplo a los demás Pueblos circunvecinos". Depois, o gobernador e os membros do Cabildo se dirigiram para o Colégio ; "haciendo entrar la Infantería y Dragones y mande [...] que juntase los Padres que allí había de la Compañía y [...] en presencia de los Oficiales y Cabildo les intimé el Decreto de su extrañamiento [...] y me retire con el Cabildo para explicarles en su lengua el Real Decreto [...] luego les presente a su nuevo Cura [...] a el cual reconocieron luego [...]." (WILDE, $2001:$ p. 84).

Tratava-se agora de consagrar uma única autoridade. Aquela do rei ausente que se presentifica pela força dos signos de seu poder, entre os quais estavam as novas autoridades que exercem o mando em seu nome. Portanto, as tentativas de reversão do descrédito em que se encontrava a Companhia não tiveram os resultados desejados.

Provavelmente, mesmo sem a presença de funcionários tão graduados como Ceballos, os outros povoados tenham também festejado em 1760 a coroação de Carlos III. Em São Borja, por força da "Relación" que a descreve, sabemos inclusive que as comemorações duraram vinte dias, transcorridos entre quatro e vinte e quatro de novembro daquele ano, de forma a incluir neste tempo, como já dissemos, o aniversário da rainha D. Amélia. Ao seu final, uma apresentação dos índios repetia : "E, pois que o céu tem dado tão grandes reis à Espanha, Todos gritem, todos digam, Com vozes e com esforço, Viva o Rei. Viva a Rainha" (Breve Relación. 1760. Apud : SEMPÉ, 1983 : p. 141). 
Apesar das mostras de boa vontade, as reduções serão submetidas à autoridade leiga depois de 1767, numa tendência que se anunciava já claramente na década anterior como se pode observar. Elas permaneceram sendo cenário de festas que, ao fim e ao cabo, iam ao encontro da importância que os guaranis emprestavam para rituais desta natureza. Seriam, contudo, outras festas.

\section{BIBLIOGRAFIA}

CARDIEL, Jose [1781]. Las misiones del Paraguay. Edición de Héctor Sáenz Ollero. Madrid : Historia $16,1989$.

CARDIEL, José. Carta y Relación de las misiones del Paraguay [1747]. In : FURLONG, Guillermo, José Cardiel y su Carta Relación. Buenos Aires : Librería del Plata, 1953.

CARTA ÂNUA DA PROVÍNCIA JESUÍTICA DO PARAGUAI - 1659-1662. Organização, Introdução e Notas FRANZEN, Beatriz Vasconcelos, FLECK, Eliane C. D. e MARTINS, Ma Cristina Bohn. CuiabáSão Leopoldo, Ed. da UFMT, OIKOS e Ed. da Unisinos, 2008.

CARTA ÂNUA DAS MISSÕES DO PARANÁ E DO URUGUAI, relativa ao ano de 1633, pelo Padre Pedro Romero ao Provincial Diego de Boroa. In : Manuscritos da Coleção de Angelis III - Jesuítas e Bandeirantes no Tape. (1615-1641) - RJ, Biblioteca Nacional, 1970. (MCA III).

CARTAS ÂNUAS DAS REDUÇÕES DO PARANÁ E URUGUAY DE 1634, ao P. Provincial Diego de Boroa. In : Manuscritos da Coleção de Angelis IV - Jesuítas e Bandeirantes no Uruguai - (1611-1758), RJ, Biblioteca Nacional, 1970. (MCA IV)

CLASTRES, Pierre. La economia primitiva. In : Investigaciones en antropología política. Gedisa : Barcelona, 1996, pp. 133-152.

CORTESÃO, Jaime. Alexandre de Gusmão e o Tratado de Madrid, RJ , 1950-1953, 9 v.

DE ANGELIS, Pedro. Colección de obras y documentos relativos a la historia antigua y moderna del Río de la Plata. Bs As, 1919, 5 v.

DURKHEIM, Emile. As formas elementares da vida religiosa. São Paulo : Martin Fontes, 2003.

ESCANDON, Juan de. SJ [1760] . Historia da transmigração dos Sete Povos Orientais. Tradução de Arnaldo Bruxel. São Leopoldo : Instituto Anchietano de Pesquisas, 1983.

FERNÁNDEZ HERRERO, Beatriz. La utopia de América. Teoría. Leyes. Experimentos. Barcelona, Anthropos 1992.

FRADKIN, Raúl e GARAVAGLIA, Juan Carlos. La Argentina Colonial. El Rio de la Plata entre los siglos XVI y XIX. Buenos Aires, Siglo XXI, 2009.

HERNÁNDEZ, Pablo. Organización Social de las Doctrinas Guaraníes. Barcelona : Gustavo Gilli, 1913.

LANGDON, Ester Jean. Rito como Conceito Chave para a Compreensão de Processos Sociais. Antropologia em Primeira Mão. 2007 . Disponível em : www.antropologia.ufsc.br/97.pdf . Acessado em julho de 2010 . 
MARTINS, Maria Cristina Bohn. Sobre festas e celebrações. Reduções do Paraguai, séculos XVII e XVIII. Passo Fundo : UPF ; ANPUH-RS, 2006.

MELIA, Bartomeu, NAGEL, Liane. El tratado de Madrid y la Guerra Guaranítica. In: Guaranies y jesuítas en tiempo de las Missiones : uma bibliografia didática. URI, CCM/ Santo Angelo ; CEPAG, Asunción, 1995, pp. 223-238.

MELIA, Bartomeu. El Guarani. Conquistado y Reducido. Ensayos de Etno-historia. Asunción : CEPAG, 1986.

NEUMANN, Eduardo. A lança e as cartas : escrita indígena e conflito nas reduções do Paraguai. História Unisinos, vol. 11, n. 2, 2007, pp. 160-172.

QUARLERI, Lía. Rebelión y guerra en las fronteras del Plata. Guaraníes, jesuítas e impérios coloniales. Buenos Aires : Fondo de Cultura Económica, 2009.

SEMPÉ, Moarci Matheus. As festas reais de São Borja em 1760. V Simpósio Nacional de Estudos Missioneiros - O espaço missioneiro, Santa Rosa, Faculdade de Filosofia, Ciências e Letras Dom Bosco, 1983, pp. 144-145.

SEPP, Antonio [1692]. Viagem às Missões jesuíticas e Trabalhos Apostólicos. Tradução de Wolfang Harnish. Editora Itatiaia, BH ; Editora da Universidade de São Paulo, SP, 1980, p. 201-202.

TORRES LONDOÑO, Fernando. Escrevendo cartas : jesuítas, escrita e missão no século XVI. In : Tempos do Sagrado. Revista Brasileira de História. São Paulo : ANPUH/Humanitas Publicações, v. 22, n. 42,2002 , pp. $11-32$.

WILDE, Guillermo. Los guaraníes después de la expulsión de los jesuita : dinâmicas políticas y transaciones simbolicas. Revista Complutense de Historia de América. n 84, 2001, 69-106.

WILDE, Guillermo. Poderes Del ritual y rituales del poder. Un análisis de las celebraciones en los pueblos jesuíticos de Guaraníes. Revista Española de Antropologia Americana. n. 33, 2003, p. 203-229, p. 206.

\section{NOTAS}

1. São Borja foi o primeiro dos sete povoados erigidos pelos jesuítas na margem oriental do rio Uruguai a partir de 1682. Fundada pelo Padre Francisco Garcia, a missão era uma extensão de Santo Tomé, de onde partiram em torno de 195 índios para darem início ao novo assentamento. Seu nome homenageava um dos mais ilustres filhos da Companhia, Francisco de Borja e Aragão (1510-1671), Duque de Gandia, Superior Geral da Ordem entre 1565 e 1572, que foi canonizado em 1671 por Clemente XI.

2. Depois de épocas conturbadas, envolvendo traslados e perdas demográficas como produto de epidemias, guerras e fugas, as reduções viviam, nesta época, um período de estabilidade. Sua população girava em torno de 100.000 índios, e seus povoados, ervais, estâncias de gado e terras de cultivo, estendiam-se por áreas das atuais repúblicas da Argentina, Uruguai, Paraguai e Brasil. Concessões especiais e vários "servicios" prestados pelos guaranis às autoridades, garantiram vantagens que contribuíram para a prosperidade econômica das reduções, como a exoneração do pagamento das "alcabalas", do dízimo sobre a produção agrícola, e da "sisa", imposto cobrado sobre certos produtos para arrecadar fundos para defesa das colônias.

3. Carlos III da Casa de Bourbon que chegou ao trono aos 54 anos, já maduro e experiente, foi o responsável por algumas das mais importantes medidas das chamadas "reformas bourbônicas". Talvez a mais conhecida delas tenha sido a que ordenou a expulsão dos jesuítas da Espanha e das 
suas colônias pelo Decreto de 27 de Fevereiro de 1767, tema diretamente relacionado a aquele que aqui analisaremos.

4. A demora na chegada das notícias não permitiu a seus homenageadores saber que, de fato, a Rainha Maria Amália, falecera em setembro deste mesmo ano, vítima de tuberculose.

5. A "Relación" não está assinada, mas Sempé (1983), que a transcreveu, sugere que tenha sido produzida pelo Pe. José Cardiel que estava em São Borja naquela oportunidade. Ele foi um missionário muito ativo, tendo evangelizado entre vários grupos indígenas. Foi também uma das vozes mais enérgicas entre os jesuítas que manifestaram contrariamente ao Tratado de Limites de 1750. Os últimos anos de sua vida americana transcorreram em Concepción, onde se encontrava quando foi detido em 10 de agosto de 1768 e embarcado na fragata San Nicolas, junto com outros 30 jesuítas. Ele foi enviado para a Itália e radicado em Faenza, como a maioria dos membros da sua antiga Província, onde faleceu em 7 de dezembro de 1781.

6. São Francisco de Borja, São Nicolau, São Miguel Arcanjo, São Lourenço Mártir, São João Batista, São Luiz Gonzaga e Santo Ângelo Custódio.

7. De parte dos interesses portugueses, há que se destacar a possibilidade que se abria assim, de exploração do território de pastagens da porção oriental das missões.

8. Os artigos 13 a 16 e 23 contêm as estipulações referentes às reduções. O Tratado pode ser consultado em várias coleções. Sugiro : DE ANGELIS, Pedro. Colección de obras y documentos relativos a la historia antigua y moderna del Río de la Plata. Bs As, 1919, 5 v.

9. Os eventos aqui rapidamente repertoriados têm sido estudados a partir de uma enorme massa documental elaborada durante os anos da resistência guarani e do conflito em si, cuja gravidade deu lugar a produção e circulação de abundante correspondência entre jesuítas, comissários designados para executar o Tratado, governadores e ministros de Estado. Mais recentemente passaram a ser analisados textos produzidos pelos próprios guaranis, redirecionando a atenção, praticamente exclusiva, que foi tradicionalmente concedida aos jesuítas como protagonistas destes eventos. É impossível, porém, e foge por certo ao escopo deste texto, inventariar esta produção, que envolve obras acadêmicas, obras de ficção e inclusive narrativas fílmicas. Desta forma, apresento aqui apenas dois trabalhos recentes, que não apenas conduzem uma boa revisão historiográfica sobre o tema, mas especialmente estudam-no sobre renovadas bases teorias teóricas e metodológicas. NEUMANN, Eduardo. A lança e as cartas : escrita indígena e conflito nas reduções do Paraguai. História Unisinos, vol. 11, n. 2, 2007, pp. 160-172 e QUARLERI, Lía. Rebelión y guerra en las fronteras del Plata. Guaraníes, jesuítas e impérios coloniales. Buenos Aires : FCE, 2009.

10. $O$ ambiente descrito não estava, é claro, restrito à Espanha, mais diretamente submetida à influência das correntes iluministas francesas. Como se sabe, também em Portugal muitas vozes creditaram o atraso do país à influência dos jesuítas. A mais destacada delas, do Marquês de Pombal, era especialmente crítica quanto a situação das populações indígenas que, no Brasil, viviam sob a tutela dos padres. Tendo ele determinado a expulsão dos jesuítas em 1759, a nova orientação será a de assimilação dos índios à sociedade colonial.

11. Estamos aqui nos referindo em particular às chamadas "cartas ânuas" que, escritas pelos Superiores no Paraguai a partir da recolha dos relatos dos missionários, apresentam uma perspectiva bastante edulcorada da vida nas reduções, o que está de acordo com o propósito edificante de que estavam revestidas. Sobre isto ver : Carta Ânua da Província Jesuítica do Paraguai 1659-1662. Organização, Introdução e Notas FRANZEN, Beatriz V., FLECK, Eliane C. D. e MARTINS, Ma Cristina Bohn. Cuiabá- São Leopoldo, Ed. da UFMT, OIKOS e Ed. da Unisinos, 2008.

12. É importante destacar que não nos reportamos aos ritos no seu sentido de atos formais, e repetitivos. Tomamos de empréstimo, ao contrário disto, as acepções do campo da antropologia, entendendo que, através dos ritos, os atores sociais estão, de alguma maneira, manifestando simbolicamente valores e ideais sobre seu mundo. Neste texto portanto, os ritos são tomados como eventos cerimoniais, com implicações religiosas e simbólicas mas também políticas. Sobre isto ver : LANGDON, Ester J. Rito como Conceito Chave para a Compreensão de Processos Sociais. 
Antropologia em Primeira Mão. 2007. Disponível em : www.antropologia.ufsc.br/97.pdf Acessado em julho de 2010.

13. A descrição feita pelo autor da Relação sobre as atenções com que os soldados brindavam os índios mais jovens (presenteando-os de várias maneiras), sugere alguma forma de assédio, o que não pode entretanto, ser mais que aventado: "Desde as primeiras representações começaram a festejá-los. Todo o dia (...) estavam lhes dando pão, passas, figos, biscoitinhos, açúcar, (...) e alguns davam-lhes pesos inteiros em uma peça. Cada dia os oficias levavam-nos à sua mesa no refeitório onde todos têm mesa à custa do Rei e acodem a ela ao som de sinos. Ali cada oficial tinha dois ou três rapazes como seus convidados. Os soldados continuamente vinham aos padres para pedirlhes licença para levar rapazes e dar-lhes de comer em suas mesas em seus quartéis" (Apud : SEMPÉ, [1760] 1983 : p. 152-153).

14. Pedro de Cevallos foi figura preponderante no panorama das disputas militares travadas entre Portugal e Espanha no sul do continente americano, entre os anos de 1762 e 1777. Em 1762 e 1763 ele derrotou lusos e britânicos na Colônia do Sacramento, conquistando posteriormente as fortalezas de Santa Teresa e São Miguel (ROU), além de Rio Grande (RS). Em 1777, já nomeado primeiro vice-rei do Rio da Prata, ele comandou ainda tomada da Ilha de Santa Catarina.

15. Não apenas a adesão dos caciques tinha que ser conquistada pelos padres como, no povoado recém-fundado, cada principal e sua família recebia, proporcionalmente às suas necessidades, os lotes de terra necessários para garantir sua existência. Isto é, a organização das missões respeitava uma das mais importantes características da economia guarani, que se organiza a partir da produção coletiva das famílias reunidas em torno de um "pai", isto é, um "chefe de linhagem".

16. Segundo Fradkin e Garavaglia, na razão contrária desta relação entre fé e lealdade política, judeus e mouros estavam simbolicamente "fora do reino", mesmo que supostamente, na prática, fossem seus habitantes. Da mesma forma, qualquer morador de qualquer localidade podia ser denunciado ao alcaide caso se recusasse a assistir a um ofício religioso, podendo vir a ser encarcerado por esta falta. Ver: FRADKIN, Raúl e GARAVAGLIA, Juan Carlos. La Argentina Colonial. El Rio de la Plata entre los siglos XVI y XIX. Buenos Aires, Siglo XXI, 2009, p. 162.

17. Manuscritos da Coleção de Angelis.

18. É sugestiva a este respeito, a concepção de Pierre Clastres (1996) sobre a "dívida" dos chefes nas sociedades tradicionais, a qual definia as posições de mando e equacionava a relação entre lideranças e liderados. Ao discutir a lógica específica de tais grupos, ele afirma que o débito no qual se funda a relação entre estas duas partes nunca se esgota ; ao contrário, ele é renovado a cada dia, ao menos enquanto durar a relação liderança-liderados. Ainda segundo o autor, a distribuição de víveres e presentes para os índios, operava como uma forma de "deslocar" em favor dos padres, aspectos da relação tradicional entre os caciques e os seus seguidores.

19. Esta participação era exclusivamente masculina. Às mulheres eram levados os alimentos em suas casas, uma vez que não podiam participar destes eventos.

20. Segundo informa Pablo Hernández (1913 : p.93 ) baseado em Cardiel, o número de cavaleiros chegaria a quinhentos ou mais : parte, da própria redução ; parte, composta por visitantes.

\section{RESUMOS}

Este artigo analisa os “Faustos Reais' ocorridos na Missão de São Borja em novembro de 1760 em comemoração à chegada ao trono de Carlos III da Espanha. Buscamos através deste episódio, 
contextualizando-o e avaliando-o em seus significados rituais e simbólicos, discutir as importantes reorientações experimentadas pelas comunidades das reduções jesuítico-guaranis na segunda metade do século XVIII. Nos importa particularmente avaliar de que forma os eventos festivos revelam as novas circunstâncias de poder e autoridade que se afirmam nestes pueblos de índios na conjuntura da crise instalada a partir do Tratado de Madrid (1750) e da Guerra Guaranítica (1753-1756).

Cet article analyse les " Fastes Royaux » qui ont eu lieu à la Mission de São Borja en novembre 1760 à l'occasion de l'arrivée du trône de Charles III d'Espagne. Nous cherchons par cet événement, en le mettant en scène et en l'évaluant dans ses sens rituels et symboliques, à discuter les importantes réorientations expérimentées par les communautés des réductions jésuitique-guaranis dans la deuxième moitié du XVIIIème siècle. Nous proposons notamment d'évaluer de quelle façon les événements festifs révèlent les nouvelles circonstances de pouvoir et d'autorité qui s'affirment dans ces "pueblos de índios" dans la conjoncture de la crise installée à partir du Traité de Madrid (1750) et de la Guerre Guaranitique (1753-1756).

\section{ÍNDICE}

Mots-clés: fêtes royales, rituel. missions, jésuites, Guaranis, Traité de Madrid

Palavras-chave: festas reais, ritual, missões, jesuítas, Guaranis, Tratado de Madrid

\section{AUTOR}

\section{MARIA CRISTINA BOHN MARTINS}

PPGH Unisinos, Doutora em História, Bolsista Produtividade CNPq

Endereço eletrônico : mcris[at]unisinos.br 